Article

\title{
Cross-National Similarities and Differences between Legacy and Digital-Born News Media Audiences
}

\author{
Alfonso Vara-Miguel \\ Department of Marketing and Media Management, School of Communication, University of Navarra, 31009 Pamplona,
} Spain; E-Mail: avara@unav.es

Submitted: 18 December 2019 | Accepted: 28 January 2020 | Published: 16 April 2020

\begin{abstract}
The decline of the news business model for print newspapers in many Western countries and the digital disruption caused by the Internet have influenced the rise of digital-born news media. These new media are different from legacy brands in terms of business models, distribution strategies, corporate organisation, and editorial priorities. It would be expected that the different nature of both legacy and digital-born news media has driven to two types of significantly different audiences. This article aims to analyse whether there are significant differences between the users of these two types of media, by comparing the online audiences of five European countries' (United Kingdom, Germany, France, Spain, and Italy) legacy and digital-born media brands in 2015 and 2019. The article will focus on four aspects: demographic and socioeconomics profiles (sex, age, income and level of education); interest in news; payment for online news; and media trust.
\end{abstract}

\section{Keywords}

digital-born media; legacy brands; media brands; media trust; paywalls

\section{Issue}

This article is part of the issue "Digital Native News Media: Trends and Challenges" edited by Ramón Salaverría (University of Navarra, Spain).

(C) 2020 by the author; licensee Cogitatio (Lisbon, Portugal). This article is licensed under a Creative Commons Attribution 4.0 International License (CC BY).

\section{Introduction}

The rise of the Internet as a content distributor is at the epicentre of the crisis of the media business model. Technological advances have reduced the entry barriers to content creation and distribution by making professional-quality production tools widely accessible at low price (Küng, 2008). The emergence of new news providers and technological distribution platforms has changed the way audiences get news (Curran, Fenton, \& Freedman, 2012; Küng, Picard, \& Towse, 2008; McDowell, 2011), making the general audience's news 'diet' more abundant and diverse than ever. According to the Digital News Report (2015 and 2019), 62\% of respondents use five or more news sources weekly $(65 \%$ in 2019), and $42 \%$ of them read seven or more different sources (45\% in 2019), from both online and/or offline outlets (Newman, Fletcher, Kalogeropoulos, \& Nielsen, 2019; Newman, Levy, \& Nielsen, 2015).
Specifically, this technological difference between online and offline products has guided research on news consumption trends, mostly from the uses and gratifications field. According to this framework, users make a rational decision, evaluating utilities, features, and rewards provided by every kind of media (Lin, Salwen, \& Abdulla, 2005). Many of these studies have focused on analysing the displacement or complementary effect of print editions by digital newspapers (Althaus \& Tewksbury, 2000; Dutta-Bergman, 2004; Flavian \& Gurrea, 2009; Newell, Pilotta, \& Thomas, 2008; Westlund \& Färdigh, 2012), with mixed results, largely due to the different methodologies applied (Chyi \& Lee, 2013). Some authors suggest that the Internet has had a competitive displacement effect on traditional media (Dimmick, Chen, \& Li, 2004; Filistrucchi, 2005; Ha \& Fang, 2012). On the contrary, Westlund and Fardigh (2015) find emerging patterns of complementary news consumption. 
Probably, the difficulty in reaching clear conclusions has its roots in the fact that the majority of studies have a technological focus: they tend to look at displacement and complementarity through platforms. However, few studies have focused on this issue from a media brands perspective. Given the increased competition and multichannel media consumption, it seems crucial for media companies to build up and strengthen their brands.

\section{Theoretical Framework}

Different media distributors and media formats used to be clearly different media products with distinctive production, marketing, and consumption patterns (McDowell, 2011). However, the Internet has led to the foundation of the so-called new pure players or digitalborn news media. These new media outlets are different from legacy brands in terms of business models, distribution strategies, corporate organisation, and editorial priorities (Nicholls, Shabbir, \& Nielsen, 2016). They only operate online and are carving out a profitable and sustainable business on the net, using new business models as the so-called niche journalism (Cook \& Sirkkunen, 2013). Meanwhile, legacy media usually manages both kinds of sources, offline (print or broadcast) and online. Although there is not a unique definition of legacy firms, they present some common traits: Their brand heritage is anchored in the quality of their customer relations, as well as in the quality of their products (McDowell, 2011; Tungate, 2005), and their consumers value legacy brand identities (Lowe \& Stavitsky, 2016). For legacy brands, it is economically rational to cover news in a quality-oriented manner. By including quality as a part of their brand identity, media outlets find an audience that is ready to pay money, or at least attention, for this sort of coverage (Siegert, Gerth, \& Rademacher, 2011). From the managerial point of view, the majority of full-time jobs for journalists are in this shrinking legacy media sector (McChesney, 2012), a sector with high costs that is vulnerable to downturns in the economy (Organization for Economic Co-operation and Development, 2010).

It would be natural to expect two different types of audience as a result of the difference between legacy and digital-born news outlets. This hypothesis is based on previous research, suggesting that users/audience perceive and use different types of news differently. Ots (2010) asserted that media brands create value for audiences wanting specific content and advertisers wanting to reach specific audiences. As a result, brand equity creates a different brand image in people's mind and so far, a different response in consumers. A strong brand will foster stronger attitudes and behaviours than those fostered by a weak or anonymous brand (Siegert, Förster, Chan-Olmsted, \& Ots, 2015). In communicating the key characteristics of legacy brands, media managers could differentiate their outlets from those of their competitors. As a result, they prevent imitation, stabilise, and increase their audience in the long term. However, there is no guarantee that audience perception of the legacy brands would be in line with media managers' intentions. In fact, contrary to expectations, legacy outlets and digital born media are not getting substantially different audiences (Arrese \& Kaufmann, 2016).

The analysis of the two kinds of audiences proposed in this article seeks to show the relevance of brands in news markets. This study complements others with a more media-centric, technological approach (Siegert et al., 2015), following the path of other scholars (Benson, Blach- Ørsten, Powers, Willig, \& Vera Zambrano, 2012; Humprecht \& Büchel, 2013; Stetka \& Örnebring, 2013).

This article focuses on three areas of research that have been analysed in previous studies of the differences and similarities between legacy media and digital-born new media: audience segmentation; revenue models; and media trust. The conclusions of this study could be of interest not only from a journalistic point of view, but from a managerial perspective.

\subsection{Audience Segmentation}

As stated above, one of the relevant topics in the studies of online and offline media has been the differences in the uses and gratifications perceived by the two types of audiences (Filistrucchi, 2005; Newell et al., 2008; Westlund \& Färdigh, 2011). New and different types of media formats should create different kinds of audiences in relation to their needs and motivations to use media and produce more audience segmentation. In that sense, the new digital landscape contributes to a greater heterogeneity in markets (Mitchelstein \& Boczkowski, 2010), due to the abundance of digital media, which incentivises the specialisation and, therefore, the targeting of smaller audiences defined by multiple and segmented interests (Arrese \& Kaufmann, 2016; Fortunati, Deuze, \& de Luca, 2014). Along the same lines, previous research has identified attitudinal variables as key factors driving the media selection process when compared with traditional media (Chyi \& Chadha, 2011; Chyi \& Lasorsa, 2002; de Waal, Schönbach, \& Lauf, 2005).

By contrast, Webster and Ksiazek (2012) assert that the Internet has concentrated a vast amount of the audience attention around the leading news organisations, which are quite undifferentiated and difficult to be segmented and predictable. According to Arrese and Kaufmann (2016), these two apparently contradictory views are not necessarily incompatible, and other reasonings must be studied to understand and find answers to the homogenisation versus segmentation debate. This article adds a new focus to this question, studying whether different types of media (legacy brands or digital-born) create significantly different readership segments.

\subsection{Revenue Models}

Over the last few years, online news organisations all over the world have erected paywalls (Arrese, 2016; 
Sjøvaag, 2016). For decades, legacy newspapers have been oriented towards protecting their current markets, serving existing customers, and reacting to innovations in media markets. They were more focused on defending their flagship brand and customer base than on being proactive (Herbert \& Thurman, 2007; Holm, 2016). However, the success of certain media firms, such as The Wall Street Journal and The New York Times (Mensing, 2007), and the need to compensate for losses in the traditional advertising market (Sjøvaag, 2016) have changed the revenue strategies of media firms, from free to pay.

An increasing amount of literature has addressed this issue from several perspectives: the effect of paywalls on the spread of quality news in society (Collins, 2011; Pickard \& Williams, 2014); the potential predictors of willingness to pay for digital news, like sociodemographic variables (Chiou \& Tucker, 2013; Chyi \& Lee, 2013; Cook \& Attari, 2012; Goyanes, 2014; Kammer, Boeck, Hansen, \& Hadberg, 2015; Wang, 2011); interest in news and frequency of readership of digital news (Goyanes \& Vara-Miguel, 2017; Oh, Animesh, \& Pinsonneault, 2016) or previous payment for print news (Chyi, 2005, 2012). Notwithstanding that, the factors related to likeliness to pay for digital news are still unclear and multifold (Himma-Kadakas \& Kõuts, 2015).

The study of revenue models from a brand perspective provides new insight into this area of research. In the online news market, with an abundant supply of news available, news has been perceived as a highly substitutable commodity, and the reluctance to pay for digital news is widespread among the public (Gundlach \& Hofmann, 2017). On the other hand, the success of certain firms is attributed to the quality and exclusiveness of the content (Vara-Miguel, Sanjurjo-San Martín, \& Díaz-Espina, 2014) and the presence of strong brands (Bleyen \& van Hove, 2010; McDowell, 2011; Mensing, 2007; Sjøvaag, 2016). The question is whether the use of legacy media versus digital-born media turns into a greater commitment to paying for digital news.

\subsection{Media Trust}

In the current media scenario, with the emergence of new alternative channels of information, some questions have arisen regarding the relationship between trust and media. Although research on media trust is abundant, the literature lacks consensus, not only on the notion of media trust, but also on the elements or dimensions that comprise it, probably due to the variety of disciplines and methodologies applied (Kiousis, 2001; Kohring \& Matthes, 2007). While early studies focus on the trust generated by sources with a clear persuasive aim (Berlo, Lemert, \& Mertz, 1969; Hovland \& Weiss, 1951), in subsequent years scholars focused on the credibility of channels and media outlets (Johnson \& Kaye, 1998; Westley $\&$ Severin, 1964) and the relationship between trust and media use (Abel \& Wirth, 1977; Gaziano \& McGrath,
1986). Most of these studies show a modest relation between media trust and media consumption, and those who trust media the most are more likely to use traditional outlets, while sceptics pay more attention to alternative sources (Ardèvol-Abreu, Hooker, \& Gil de Zúñiga, 2018; Fletcher \& Park, 2017; Kiousis, 2001; Tsfati, 2010; Tsfati \& Cappella, 2003, 2005).

Finally, recent worries about fake news, misinformation, and the often-low trust in the news have highlighted the value of legacy brands as trusted media. According to the Digital News Report (Newman et al., 2019), over a quarter $(26 \%)$ of the respondents have started to rely on more reputable news sources ( $40 \%$ in the US), and a further quarter have stopped using sources of dubious reputation. The analysis of media trust from this brand perspective could help to understand whether trust is perceived as a significant asset of legacy media when compared with digital-born media.

\section{Research Questions and Hypothesis}

As stated above, the aim of this article is to investigate whether the nature of legacy media brands or digitalborn media is relevant in explaining audience differentiation in online news markets, considering the issues discussed in the previous section. More specifically, this article analyses whether or not there are significant differences between online users of these two types of media firms by comparing the digital audiences of the main legacy and digital-born media brands of five European countries (United Kingdom, Germany, France, Spain, and Italy) in 2015 and 2019. The specific research questions are as follows:

RQ1. Do online audiences of legacy media and digitalborn media have significantly different demographic and socioeconomic profiles?

RQ2. Are online audiences of legacy media and digitalborn media significantly different in their interest in news and in their frequency of news consumption?

RQ3. Do online audiences of legacy media and digitalborn media differ significantly in their behaviour and attitudes toward payment for online news content?

RQ4. Do online audiences of legacy media and digitalborn media differ significantly in their media trust perception?

The general hypothesis is that significant differences exist in all of the questions under research, something that seems reasonable considering the different natures of these two types of media firms. A priori, it could be stated that legacy brands have a similar audience, in terms of profile and behaviour, to that of traditional media outlets (higher age, income and level of education; RQ1), they declare more interest in news and, con- 
sequently, access news more frequently (RQ2) and are more likely to pay for digital news (RQ3). Finally, legacy users are more inclined to trust mass media and are more sceptical about social media (RQ4), in contrast to digitalborn media audiences.

\section{Method}

\subsection{Sample, Variables, and Measurement}

The analysis is based on data corresponding to the United Kingdom, Germany, France, Spain, and Italy from the survey carried out for the Digital News Report 2015 and 2019, in which some questions directly related to this article were included. YouGov, using an online questionnaire in late January-early February 2014 and 2019 , conducted the survey fieldwork, commissioned by the Reuters Institute for the Study of Journalism. The data were weighted to targets based on census/industryaccepted data, such as age, gender, region, newspaper readership, and social grade, to reflect the population of each country. The sample is reflective of the adult population $(18+)$ with access to the Internet. As the survey deals with news consumption, it filtered out anyone who said that they had not consumed any news in the past month (average around 3\%) in order to ensure that irrelevant responses did not adversely affect data quality (see Table 1).

In order to get the two types of readers (legacy users and digital-born users), a subsample was generated using the responses to the question: 'Which, if any, of the following have you used to access news in the last week via online platforms (web, mobile, tablet, e-reader)? Please select all that apply.' Respondents have to select options from a list of each country's main legacy and digital-born outlets. According to their responses, two types of readers were obtained: those who use more legacy media than digital-born media and those who use more digital-born media than legacy outlets $\left(N_{2015}=6,677,65.8 \%\right.$ of the total sample; $N_{2019}=6,532$, $64.9 \%$ of the total sample). Additionally, those who use exactly the same number of legacy and digital-born media have been excluded from the subsample in order to have two clear-cut groups.

Once the grouping variable is established, we select those survey questions used as variables to examine the hypotheses related to the RQs. All the variables, as explained below, should be considered as reasonable-not exhaustive-proxy measures for the overarching characteristics under investigation.

Demographic and socioeconomic profiles (RQ1) were measured through four variables: gender (male/female); age (18 to 24,25 to 34,35 to 44,45 to 54,55 to 64 , and 65 or more); household income (low income, less than $€ 19,999$; medium income, $€ 20,000$ to $€ 39,999$; high income, $€ 40,000$ or more); and education level (no completed secondary school/completed high school or Bac-A levels/completed professional qualification/completed bachelor's degree/completed master's or doctoral degree).

Interest in news and frequency of news consumption (RQ2) were measured through the following questions: 'How interested, if at all, would you say you are in the news?' (extremely interested/very interested/somewhat interested/not very interested/not at all interested) and 'Typically, how often do you access news? By news we mean national, international, regional/local news and other topical events accessed via any platform (radio, TV, newspaper, or online)' (less often than once a week/once a week to six times a week/once a day to five times a day/six times a day or more).

Attitudes towards payment for digital news were used as proxy indicators of the preference for revenue models more dependent on free or paid content (RQ3). The exact question asked was 'Have you paid for online news content, or accessed a paid online news service in the last year? (this could be digital subscription, combined digital/print subscription or one-off payment for an article or app)' (yes/no).

Finally, we measured the media trust (RQ4) of the audience through two questions. The first, 'Thinking about news in general, do you agree or disagree with the following statement? "I think you can trust most news most of the time,"' focused on the credibility of the media in general, but the second asked about the audience's trust in the specific media outlets they used: 'Thinking specifically about news sources that you use, do you agree or disagree with the following statement? "I think I can trust most of the news that I use most of the time."' The possible answers to both questions were strongly disagree/tend to disagree/neither agree nor disagree/tend to agree/strongly agree.

Table 1. Sample size and internet penetration (2015 and 2019).

\begin{tabular}{lcccc}
\hline & \multicolumn{2}{c}{2015} & 2019 \\
\hline Country & Sample size & Internet penetration & Sample size & Internet penetration \\
\hline United Kingdom & 2,149 & $90 \%$ & 2,023 & $95 \%$ \\
Germany & 1,969 & $89 \%$ & 2,022 & $96 \%$ \\
France & 1,991 & $83 \%$ & 2,005 & $93 \%$ \\
Spain & 2,026 & $75 \%$ & 2,005 & $93 \%$ \\
Italy & 2,006 & $59 \%$ & 2,006 & $92 \%$ \\
\hline
\end{tabular}

Source: Internet World Stats (n.d.). 
Table 2. Subsample: Legacy and digital-born users (2015 and 2019).

\begin{tabular}{|c|c|c|c|c|c|c|c|c|}
\hline \multirow[b]{3}{*}{ Country } & \multicolumn{4}{|c|}{2015} & \multicolumn{4}{|c|}{2019} \\
\hline & \multirow[b]{2}{*}{ Legacy users } & \multicolumn{3}{|c|}{ Digital-born } & \multicolumn{4}{|c|}{ Digital-born } \\
\hline & & $\%$ & users & $\%$ & Legacy users & $\%$ & users & $\%$ \\
\hline United Kingdom & 1,238 & $86.9 \%$ & 186 & $13.1 \%$ & 1,294 & $92.0 \%$ & 112 & $8.0 \%$ \\
\hline Germany & 999 & $82.2 \%$ & 217 & $17.8 \%$ & 9,24 & $73.9 \%$ & 327 & $26.1 \%$ \\
\hline France & 783 & $70.9 \%$ & 321 & $29.1 \%$ & 786 & $72.9 \%$ & 292 & $27.1 \%$ \\
\hline Spain & 1,170 & $80.9 \%$ & 276 & $19.1 \%$ & 1,182 & $83.1 \%$ & 240 & $16.9 \%$ \\
\hline Italy & 1,142 & $76.8 \%$ & 345 & $23.2 \%$ & 1,118 & $81.3 \%$ & 257 & $18.7 \%$ \\
\hline Total & 5,332 & $79.9 \%$ & 1,345 & $20.1 \%$ & 5,304 & $81.2 \%$ & 1,228 & $18.8 \%$ \\
\hline
\end{tabular}

\subsection{Statistical Analysis}

We decided to use the chi-squared test to analyse categorical variables (gender, income, and payment for online news) and the Mann-Whitney U-test for metric variables (education, age, interest in news, frequency of news consumption, media trust, and trust in your own media). The selection of non-parametric tests, including metric variables, was due to the lack of normality in the distribution of values. An examination of the standardised skewness coefficient and the standardised kurtosis coefficient revealed serious departures from normality for all of the metric variables.

\section{Results}

Table 2 shows the distribution and evolution of the two audience groups. Most of the respondents used more legacy media than digital-born media as a source of news in all of the countries studied. Five years later, this trend was stronger and the percentage of respondents getting news from legacy media grew in every country except Germany.

In order to test if a significant difference exists between the groups of readers in terms of sociodemographic variables (RQ1), a chi-squared was used to analyse gender and income and a Mann-Whitney U-test was applied for age and level of education. The data revealed a statistically significant difference in 2015 between groups in gender $\left(X^{2}(1, N=6,677)=23.65, p=0.000\right)$, income $\left(X^{2}(2, N=5,880)=16.68, p=0.000\right)$, and education $(U=3300886, p=0.000)$, but not age $(U=3471020$, $p=0.065)$. Table 3 shows that in 2015, male audiences (52\%) with high income (28\%) and a bachelor's or postgraduate degree (38\%) tend to use more legacy media than born-digital. Five years later, there were significant differences in all sociodemographic variables: gender $\left(X^{2}(1, N=6,531)=26.24, p=0.000\right)$; income $\left(X^{2}(2, N=5,651)=11.90, p=0.003\right)$, education $(U=3202889, p=0.000)$; and age $(U=3082176$, $p=0.000)$.

Table 4 shows the same trend in 2019. Those who use more legacy media than born-digital media tend to be male, with higher levels of income and education than those who read more digital-born outlets. Surprisingly, respondents under 44 years read more legacy brands (45\%) than born-digital media (33\%), while those over 45 years use more native media (66\%) than legacy media (54\%).

By countries, the data shows that Spain and especially France differ from the general trend, as there are no sociodemographic differences between the two groups in these countries, either in 2015 or in 2019.

With regard to the amount of interest in news and the level of news consumption (RQ2), the data shows significant differences between the two groups in 2015interest in news $(U=3051343, p=0.000)$ and frequency of news use $(U=3185492, p=0.000)$-and in 2019interest in news $(U=2922834, p=0.000)$ and frequency of news use $(U=3012158, p=0.000)$.

In 2015 (see Table 5), those who use more legacy media were more interested in news (34\% are extremely interested, versus $24 \%$ of native users) and read news more frequently (61\% of legacy users access six times a day or more, versus $50 \%$ of born-digital users). Five years later (see Table 6), the data shows similar differences between the two groups: $30 \%$ of legacy users are extremely interested in news, versus $21 \%$ of native users, and the $27 \%$ of them access 6 times a day or more to news, versus the $17 \%$ of born-digital users. The differences between the two groups of users occur in all the countries analysed, except France in 2015, where there are no significant differences in both variables: interest in news $(U=120539$, $p=0.257)$ and frequency of news use $(U=124422$, $p=0.770$ ). However, in 2019, significant differences appear between the two groups of French users.

The results on attitudes toward payment for online news content (RQ3) show also significant differences between the two groups in $2015\left(X^{2}(1, N=6,557)=20.23\right.$, $p=0.000)$ and $2019\left(X^{2}(1, N=6,333)=30.20, p=0.000\right)$. In 2015 (see Table 5), those who read more legacy brands than born-digital media were more likely to pay for online news (12\%) than those who use native media (8\%). In 2019 , the percentages were $13 \%$ and $7 \%$, respectively (see Table 6). Significant differences occur in all countries except France $\left(X^{2}(1, N=1,078)=3.17, p=0.075\right)$ and Spain $\left(X^{2}(1, N=1,426)=2.79, p=0.094\right)$ in 2015, and Italy in $2019\left(X^{2}(1, N=1,310)=1.63, p=0.201\right)$. 
Table 3. Frequency distributions for sociodemographic variables, 2015 (\%).

\begin{tabular}{|c|c|c|c|c|c|c|c|c|c|c|c|c|}
\hline & \multicolumn{6}{|c|}{ Legacy users } & \multicolumn{6}{|c|}{ Born-digital users } \\
\hline & Total & UK & GER & $\mathrm{FR}$ & SP & IT & Total & UK & GER & $\mathrm{FR}$ & SP & IT \\
\hline \multicolumn{13}{|l|}{ Sociodemographic } \\
\hline \multicolumn{13}{|l|}{ Gender } \\
\hline Male & 52.4 & 52.3 & 55.6 & 51.5 & 52.6 & 50.1 & 45.0 & 36.6 & 47.0 & 47.7 & 45.3 & 45.5 \\
\hline Female & 47.6 & 47.7 & 44.4 & 48.5 & 47.4 & 49.9 & 55.0 & 63.4 & 53.0 & 52.3 & 54.7 & 54.5 \\
\hline \multicolumn{13}{|l|}{ Age } \\
\hline 18 to 24 & 9.5 & 11.3 & 10.4 & 6.4 & 10.2 & 8.1 & 8.3 & 14.0 & 2.3 & 4.7 & 8.0 & 12.5 \\
\hline 25 to 34 & 15.9 & 13.3 & 16.6 & 12.4 & 19.9 & 16.5 & 15.3 & 11.8 & 9.7 & 14.0 & 19.9 & 18.3 \\
\hline 35 to 44 & 19.1 & 16.3 & 19.7 & 16.6 & 22.6 & 19.6 & 19.0 & 9.7 & 18.4 & 19.6 & 22.5 & 20.9 \\
\hline 45 to 54 & 18.5 & 20.4 & 18.4 & 17.6 & 18.2 & 17.3 & 18.4 & 21.5 & 23.0 & 18.7 & 15.2 & 15.9 \\
\hline 55 to 64 & 23.9 & 22.0 & 19.6 & 29.5 & 23.2 & 26.7 & 24.5 & 22.6 & 24.0 & 25.2 & 27.5 & 22.6 \\
\hline 65 or more & 13.1 & 16.6 & 15.2 & 17.5 & 5.9 & 11.6 & 14.6 & 20.4 & 22.6 & 17.8 & 6.9 & 9.9 \\
\hline \multicolumn{13}{|l|}{ Household income } \\
\hline Low & 22.2 & 22.9 & 22.6 & 18.5 & 25.0 & 20.5 & 23.8 & 36.7 & 29.4 & 13.0 & 27.7 & 20.3 \\
\hline Medium & 49.1 & 45.3 & 49.8 & 56.3 & 45.3 & 51.5 & 53.4 & 45.6 & 48.5 & 62.7 & 48.2 & 56.3 \\
\hline High & 28.7 & 31.8 & 27.5 & 25.2 & 29.7 & 27.9 & 22.8 & 17.7 & 22.2 & 24.3 & 24.1 & 23.3 \\
\hline \multicolumn{13}{|l|}{ Education } \\
\hline No completed Sec. school & 10.0 & 9.1 & 9.1 & 15.2 & 7.2 & 11.1 & 12.3 & 12.4 & 9.7 & 14.0 & 6.2 & 17.1 \\
\hline Completed High school & 31.2 & 30.5 & 24.0 & 28.6 & 23.9 & 47.4 & 33.5 & 32.8 & 23.5 & 31.2 & 21.4 & 52.2 \\
\hline Prof. Qualification & 20.9 & 16.0 & 36.4 & 24.9 & 23.4 & 7.1 & 23.0 & 24.2 & 45.2 & 23.4 & 27.5 & 4.3 \\
\hline Bachelor's & 23.3 & 30.7 & 15.3 & 18.8 & 37.0 & 11.3 & 20.9 & 24.7 & 12.4 & 19.9 & 38.0 & 11.3 \\
\hline Master's/Doctoral & 14.7 & 13.7 & 15.1 & 12.5 & 8.5 & 23.1 & 10.3 & 5.9 & 9.2 & 11.5 & 6.9 & 15.1 \\
\hline
\end{tabular}

Table 4. Frequency distributions for sociodemographic variables, 2019 (\%).

\begin{tabular}{|c|c|c|c|c|c|c|c|c|c|c|c|c|}
\hline & \multicolumn{6}{|c|}{ Legacy users } & \multicolumn{6}{|c|}{ Born-digital users } \\
\hline & Total & UK & GER & FR & SP & IT & Total & UK & GER & FR & SP & IT \\
\hline \multicolumn{13}{|l|}{ Sociodemographic } \\
\hline \multicolumn{13}{|l|}{ Gender } \\
\hline Male & 51.9 & 50.8 & 55.1 & 52.2 & 51.9 & 50.6 & 43.9 & 52.3 & 42.2 & 40.8 & 46.4 & 43.6 \\
\hline Female & 48.1 & 49.2 & 44.9 & 47.8 & 48.1 & 49.4 & 56.1 & 47.7 & 57.8 & 59.2 & 53.6 & 56.4 \\
\hline \multicolumn{13}{|l|}{ Age } \\
\hline 18 to 24 & 10.8 & 12.3 & 12.1 & 12.5 & 9.4 & 8.3 & 6.8 & 12.5 & 2.8 & 9.2 & 4.6 & 8.5 \\
\hline 25 to 34 & 16.6 & 17.4 & 16.5 & 18.6 & 16.5 & 14.4 & 12.2 & 17.9 & 11.0 & 12.7 & 10.4 & 12.4 \\
\hline 35 to 44 & 17.8 & 17.3 & 17.1 & 14.6 & 21.7 & 17.0 & 14.9 & 16.1 & 12.5 & 18.5 & 13.3 & 14.7 \\
\hline 45 to 54 & 18.2 & 16.6 & 19.0 & 15.4 & 19.6 & 20.0 & 20.7 & 14.3 & 21.4 & 19.5 & 21.7 & 22.9 \\
\hline 55 to 64 & 21.4 & 15.8 & 20.5 & 19.6 & 24.5 & 26.8 & 29.5 & 12.5 & 35.8 & 22.6 & 38.3 & 28.3 \\
\hline 65 or more & 15.2 & 20.6 & 14.7 & 19.4 & 8.3 & 13.5 & 16.0 & 26.8 & 16.5 & 17.5 & 11.7 & 13.2 \\
\hline \multicolumn{13}{|l|}{ Household income } \\
\hline Low & 28.9 & 25.0 & 27.6 & 31.8 & 33.8 & 26.7 & 29.0 & 35.9 & 22.6 & 32.9 & 32.6 & 26.0 \\
\hline Medium & 47.1 & 44.3 & 47.8 & 39.7 & 44.9 & 57.2 & 51.6 & 42.4 & 62.2 & 40.2 & 46.5 & 60.2 \\
\hline High & 24.0 & 30.7 & 24.6 & 28.5 & 21.3 & 16.2 & 19.4 & 21.7 & 15.2 & 26.9 & 20.9 & 13.9 \\
\hline \multicolumn{13}{|l|}{ Education } \\
\hline No completed Sec. school & 31.4 & 22.9 & 22.9 & 23.3 & 43.7 & 41.2 & 33.1 & 28.6 & 26.0 & 23.3 & 42.7 & 46.1 \\
\hline Completed High school & 26.6 & 14.9 & 35.8 & 32.8 & 18.0 & 37.4 & 32.9 & 16.1 & 40.7 & 36.6 & 19.2 & 38.8 \\
\hline Prof. Qualification & 14.5 & 18.9 & 16.5 & 18.2 & 14.0 & 5.7 & 15.3 & 22.3 & 17.4 & 21.6 & 13.0 & 4.7 \\
\hline Bachelor's & 16.4 & 30.3 & 11.5 & 9.9 & 19.0 & 6.3 & 9.7 & 28.6 & 6.1 & 5.8 & 17.2 & 3.5 \\
\hline Master's/Doctoral & 11.0 & 13.0 & 13.3 & 15.8 & 5.3 & 9.4 & 9.0 & 4.5 & 9.8 & 12.7 & 7.9 & 7.0 \\
\hline
\end{tabular}


Table 5. Frequency distributions for media use, payment and media trust variables, 2015 (\%).

\begin{tabular}{|c|c|c|c|c|c|c|c|c|c|c|c|c|}
\hline & \multicolumn{6}{|c|}{ Legacy users } & \multicolumn{6}{|c|}{ Born-digital users } \\
\hline & Total & UK & GER & $\mathrm{FR}$ & SP & IT & Total & UK & GER & FR & SP & IT \\
\hline \multicolumn{13}{|l|}{ Media use and payment } \\
\hline \multicolumn{13}{|l|}{ Frequency news use } \\
\hline Less often once a week & 2.4 & 2.2 & 2.4 & 3.8 & 2.2 & 1.7 & 3.8 & 4.3 & 1.8 & 3.7 & 3.6 & 4.9 \\
\hline Once a week to 6 times a week & 6.5 & 6.6 & 7.3 & 7.9 & 6.4 & 4.8 & 8.3 & 11.8 & 7.8 & 4.7 & 8.7 & 9.9 \\
\hline Once a day to 5 times a day & 30.1 & 25.2 & 23.9 & 31.4 & 40.3 & 29.6 & 37.7 & 38.2 & 34.1 & 37.4 & 44.9 & 34.2 \\
\hline 6 times a day or more & 61.0 & 66.0 & 66.4 & 56.8 & 51.0 & 63.9 & 50.2 & 45.7 & 56.2 & 54.2 & 42.8 & 51.0 \\
\hline \multicolumn{13}{|l|}{ Interest in news } \\
\hline Extremely interested & 34.6 & 31.6 & 37.5 & 25.9 & 35.6 & 40.2 & 24.5 & 19.4 & 26.7 & 23.1 & 29.9 & 23.5 \\
\hline Very interested & 45.7 & 46.2 & 45.4 & 41.4 & 54.2 & 39.9 & 45.8 & 41.9 & 48.4 & 41.7 & 55.1 & 42.6 \\
\hline Somewhat interested & 18.3 & 20.7 & 16.2 & 28.9 & 9.8 & 18.9 & 27.1 & 33.9 & 23.5 & 30.2 & 15.6 & 31.9 \\
\hline Not very interested & 1.3 & 1.4 & 0.7 & 3.8 & 0.3 & 1.0 & 2.3 & 4.3 & 0.5 & 4.3 & 0.0 & 2.0 \\
\hline Not at all interested & 0.1 & 0.2 & 0.2 & 0.0 & 0.1 & 0.0 & 0.4 & 0.5 & 0.9 & 0.5 & 0.4 & 0.0 \\
\hline \multicolumn{13}{|l|}{ Pay for digital news } \\
\hline Yes & 12.5 & 8.5 & 11.1 & 13.5 & 14.0 & 15.6 & 8.0 & 4.3 & 5.6 & 9.6 & 10.2 & 8.4 \\
\hline No & 87.5 & 91.5 & 88.9 & 86.5 & 86.0 & 84.4 & 92.0 & 95.7 & 94.4 & 90.4 & 89.8 & 91.6 \\
\hline \multicolumn{13}{|l|}{ Media trust } \\
\hline \multicolumn{13}{|l|}{ I can trust media } \\
\hline Strongly disagree & 4.6 & 3.9 & 5.0 & 4.9 & 5.6 & 3.8 & 5.5 & 7.0 & 1.8 & 5.9 & 6.9 & 5.5 \\
\hline Tend to disagree & 20.8 & 20.8 & 12.2 & 19.5 & 27.6 & 22.3 & 21.0 & 21.5 & 8.3 & 23.4 & 27.5 & 21.4 \\
\hline Neither agree nor disagree & 29.9 & 23.5 & 23.3 & 34.4 & 33.1 & 36.3 & 32.5 & 30.6 & 23.0 & 33.0 & 31.5 & 39.7 \\
\hline Tend to agree & 40.4 & 48.1 & 49.3 & 38.8 & 31.4 & 34.6 & 37.3 & 39.2 & 57.6 & 34.3 & 31.9 & 30.7 \\
\hline Strongly agree & 4.3 & 3.8 & 10.1 & 2.4 & 2.3 & 3.0 & 3.6 & 1.6 & 9.2 & 3.4 & 2.2 & 2.6 \\
\hline \multicolumn{13}{|l|}{ I can trust my own media } \\
\hline Strongly disagree & 2.9 & 2.7 & 2.6 & 2.8 & 3.8 & 2.5 & 2.6 & 2.2 & 0.9 & 3.1 & 4.3 & 2.0 \\
\hline Tend to disagree & 15.2 & 12.2 & 7.4 & 13.7 & 24.4 & 17.1 & 15.5 & 17.2 & 6.0 & 17.1 & 19.2 & 16.2 \\
\hline Neither agree nor disagree & 24.8 & 18.6 & 22.0 & 29.4 & 27.0 & 28.8 & 28.6 & 24.2 & 23.0 & 31.8 & 25.7 & 33.6 \\
\hline Tend to agree & 50.7 & 58.9 & 53.9 & 50.1 & 42.1 & 48.1 & 48.1 & 51.6 & 57.1 & 43.6 & 47.1 & 45.5 \\
\hline Strongly agree & 6.4 & 7.7 & 14.1 & 4.1 & 2.6 & 3.5 & 5.2 & 4.8 & 12.9 & 4.4 & 3.6 & 2.6 \\
\hline
\end{tabular}

Finally, the analysis of the groups' media trust perception (RQ4) does not provide a clear conclusion. Although both types of readers show significant differences in $2015(U=3453343, p=0.027)$ and $2019(U=3341165$, $p=0.039)$ and those who use more legacy brands than digital-born media show higher media trust $(44 \%$ of legacy respondents usually trust on news versus $40 \%$ of native users in $2015 ; 40 \%$ and $37 \%$ in 2019 , respectively; see Tables 5 and 6), there are some differences in the five countries analysed. In 2015, the data show no significant differences between the two types of users in Spain $(U=159969, p=0.803)$, Italy $(U=188917, p=0.223)$, and France $(U=119280, p=0.161)$. However, the similarity in the Spanish and Italian audience is around the distrust on media, while in France is around trust. As Table 5 shows, only a third of Spanish and Italian respondents usually trust the news, in contrast with $41 \%$ of the French users. That is, distrust is widespread in Spain and Italy in 2015, regardless of the type of media outlet, while in France, trust is the common ground for both groups.
Five years later (see Table 6), there are no differences between the two types of readers in France $(U=125871$, $p=0.966)$, Germany $(U=140053, p=0.063)$, and Italy $(U=137063, p=0.181)$. In this case, French users coincide in their media distrust, regardless of the kind of outlet (only a quarter of French respondents usually trust media), while in Germany and Italy it is the opposite.

Additionally, we found no evidence of the third person effect (Davison, 1983; Perloff, 2009) in the research. The differences between groups in all countries (except Spain) are identical in $2015(U=3463762, p=0.037)$ and $2019(U=3315316, p=0.011)$ when users were asked about the trust they have in the news that they usually read.

\section{Conclusion}

The data confirms that, although the online news market continues to be dominated by legacy brands (Bruno $\&$ Nielsen, 2012) and the most popular sites are those 
Table 6. Frequency distributions for media use, payment and media trust variables, 2019 (\%).

\begin{tabular}{|c|c|c|c|c|c|c|c|c|c|c|c|c|}
\hline & \multicolumn{6}{|c|}{ Legacy users } & \multicolumn{6}{|c|}{ Born-digital users } \\
\hline & Total & UK & GER & FR & SP & IT & Total & UK & GER & $\mathrm{FR}$ & SP & IT \\
\hline \multicolumn{13}{|l|}{ Media use and payment } \\
\hline \multicolumn{13}{|l|}{ Frequency news use } \\
\hline Less often once a week & 0.7 & 1.2 & 0.5 & 0.5 & 0.8 & 0.5 & 1.6 & 3.6 & 1.6 & 2.1 & 0.4 & 1.6 \\
\hline Once a week to 6 times a week & 7.5 & 7.7 & 8.3 & 7.9 & 7.3 & 6.5 & 9.4 & 14.3 & 8.7 & 9.2 & 9.3 & 8.7 \\
\hline Once a day to 5 times a day & 64.0 & 62.3 & 61.0 & 66.5 & 69.1 & 61.3 & 71.6 & 67.9 & 71.4 & 74.0 & 78.5 & 64.2 \\
\hline 6 times a day or more & 27.8 & 28.9 & 30.2 & 25.1 & 22.8 & 31.6 & 17.3 & 14.3 & 18.3 & 14.7 & 11.8 & 25.6 \\
\hline \multicolumn{13}{|l|}{ Interest in news } \\
\hline Extremely interested & 30.7 & 32.8 & 34.6 & 20.8 & 30.9 & 31.7 & 21.7 & 19.6 & 26.8 & 12.4 & 24.3 & 24.3 \\
\hline Very interested & 43.0 & 41.3 & 43.7 & 41.1 & 50.9 & 37.5 & 40.0 & 32.1 & 41.5 & 35.7 & 54.0 & 33.3 \\
\hline Somewhat interested & 23.5 & 23.7 & 18.8 & 32.4 & 16.1 & 28.5 & 33.1 & 37.5 & 25.8 & 47.4 & 20.9 & 35.3 \\
\hline Not very interested & 2.4 & 1.9 & 2.0 & 4.5 & 1.8 & 2.3 & 4.3 & 8.9 & 4.9 & 3.8 & 0.8 & 5.5 \\
\hline Not at all interested & 0.5 & 0.2 & 1.0 & 1.2 & 0.3 & 0.1 & 0.9 & 1.8 & 0.9 & 0.7 & & 1.6 \\
\hline \multicolumn{13}{|l|}{ Pay for digital news } \\
\hline Yes & 13.0 & 12.1 & 13.6 & 15.1 & 13.2 & 11.8 & 7.3 & 4.6 & 4.4 & 9.8 & 8.0 & 8.9 \\
\hline No & 87.0 & 87.9 & 86.4 & 84.9 & 86.8 & 88.2 & 92.7 & 95.4 & 95.6 & 90.2 & 92.0 & 91.1 \\
\hline
\end{tabular}

Media trust

I can trust media

Strongly disagree

Tend to disagree

Neither agree nor disagree

Tend to agree

Strongly agree

I can trust my own media

Strongly disagree

Tend to disagree

Neither agree nor disagree

Tend to agree

Strongly agree

\begin{tabular}{rrrrrrrrrrrr}
9.1 & 7.9 & 6.7 & 18.4 & 9.6 & 5.5 & 10.3 & 9.7 & 6.7 & 16.4 & 14.2 & 4.3 \\
22.1 & 25.8 & 19.2 & 29.4 & 20.6 & 16.9 & 22.8 & 33.6 & 12.2 & 32.2 & 23.3 & 20.2 \\
27.8 & 25.0 & 27.8 & 27.4 & 24.3 & 35.1 & 29.3 & 23.9 & 29.1 & 27.7 & 24.2 & 38.5 \\
36.1 & 38.2 & 39.1 & 23.1 & 38.1 & 38.1 & 33.4 & 31.0 & 47.1 & 22.3 & 29.2 & 33.9 \\
4.8 & 3.1 & 7.3 & 1.7 & 7.4 & 4.4 & 4.2 & 1.8 & 4.9 & 1.4 & 9.2 & 3.1 \\
& & & & & & & & & & & \\
4.9 & 4.2 & 2.1 & 9.1 & 6.3 & 3.8 & 5.0 & 7.1 & 4.3 & 6.8 & 6.3 & 1.9 \\
16.4 & 17.7 & 11.2 & 20.7 & 18.7 & 14.0 & 19.0 & 31.3 & 8.3 & 23.6 & 24.7 & 16.7 \\
26.7 & 23.9 & 24.5 & 30.4 & 24.5 & 31.6 & 27.9 & 18.8 & 21.7 & 34.2 & 25.9 & 34.5 \\
44.8 & 49.0 & 50.7 & 35.8 & 40.9 & 45.3 & 41.8 & 42.0 & 58.4 & 31.8 & 31.4 & 41.5 \\
7.2 & 5.3 & 11.6 & 3.9 & 9.7 & 5.4 & 6.3 & 0.9 & 7.3 & 3.4 & 11.7 & 5.4 \\
\hline
\end{tabular}

of major news organisations (McDowell, 2011), digitalborn media have become part of the media ecosystem in all the countries analysed. This article confirms the divergence between legacy media users and native users. By and large, legacy users tend to be male and with higher income and education levels than native users (RQ1). However, cross-national data are not homogeneous in all countries.

It is interesting to note that the two groups of users differ more when journalistic variables are analysed (RQ2 and RQ3). In all countries (except France in both years), legacy brands audiences show greater interest, more news consumption, and more willingness to pay for digital news than the digital-born users.

In relation to media trust, data about the existence (or not) of differences between the two groups are less clear (RQ4). Global data shows significant differences in 2015 and 2019, and those who use more legacy brand than digital-born outlets are more likely to trust the news. In that sense, media scepticism is more widespread among native users.
Finally, the longitudinal analysis shows that in 2019, the percentage of very interested and heavy users decreased in both groups from 2015, although more intensely among native users. Additionally, trust in news also declined in 2019 in both types of users, especially among digital-born outlet readers (from $40.9 \%$ to $37.6 \%)$.

This data could demonstrate the strength of legacy brands, and its ability to get and keep loyal customers. As a whole, all the indicators analysed (interest, reading frequency, payment for news, and trust) are more positive to legacy media. And when they decreased in 2019, they did with less intensity than the native ones, widening the gap between the two groups. From a managerial viewpoint, legacy brands have three strong competitive advantages over digital-born media. Firstly, they enjoy a better differentiation in relation to competitors, not only in sociodemographic terms. Secondly, legacy media users show a higher engagement and tendency to loyalty to their brands. Thirdly, this engagement drives to a higher desire to continue buying the same brand, at least 
in a higher percentage than native users (Chan-Olmsted, 2011). Any global news branding strategy should be based on these ideas, as brand recognition constitute the baseline from which to get and keep loyal customers. By far, this conclusion does not underestimate the role that digital-born outlets could play in the media landscape. Even if legacy media organisations succeed in moving readers towards paywalls, free alternatives are likely to remain in news markets (Sjøvaag, 2016).

Although a complete review of the factors contributing to media trust is beyond the scope of this study, a deeper look at this variable is necessary. Taken as a whole, the data shows the existence of significant differences among legacy users and native users in both years, as the former are more likely to rely more on news than the latter. This is not surprising, as native media were born in many cases as an alternative to legacy options, perceived as unreliable, mostly by younger people, as confirmed in previous studies (Tsfati, 2010; Tsfati \& Cappella, 2003, 2005). Brand reputation could be a crucial factor in the trust transfer process from traditional media outlets to digital ones. Those who read more legacy media trust more in news, no matter the channel (traditional or digital) used. This is an additional competitive advantage for legacy brands, and any media brand extension strategy should be based on this idea.

However, the analysis by countries suggests a need for deeper research on other factors (like national media systems or institutional media trust) that could explain better why France and Italy there are no significant differences between the two groups in 2015 and 2019; why native users in Germany show greater confidence in the news than legacy users in both years; or why, when institutional trust in media is widespread (such as in France in 2015 or Germany in 2019), there are no differences between legacy and native users. The relevance of these studies could improve the strategies for the media to follow in order to avoid the dilution of the differential value of legacy brands.

\section{Acknowledgments}

This work was supported by the Spanish Ministry of Science, Innovation and Universities (Research Project DIGINATIVEMEDIA, Reference No. RTI2018-093346-BC31).

\section{Conflict of Interests}

The author declares no conflict of interests.

\section{References}

Abel, J. D., \& Wirth, M. O. (1977). Newspaper vs. TV credibility for local news. Journalism Quarterly, 54(2), 371-375. https://doi.org/10.1177/1077699077054 00223

Althaus, S. L., \& Tewksbury, D. (2000). Patterns of inter- net and traditional news media use in a networked community. Political Communication, 17(1), 21-45.

Ardèvol-Abreu, A., Hooker, C. M., \& Gil de Zúñiga, H. (2018). Online news creation, trust in the media, and political participation: Direct and moderating effects over time. Journalism, 19(5), 611-631. https:// doi.org/10.1177/1464884917700447

Arrese, Á. (2016). From gratis to paywalls. Journalism Studies, 17(8), 1051-1067. https://doi.org/10.1080/ 1461670X.2015.1027788

Arrese, Á., \& Kaufmann, J. (2016). Legacy and native news brands online: Do they show different news consumption patterns? International Journal on Media Management, 18(2), 75-97. https://doi.org/ 10.1080/14241277.2016.1200581

Benson, R., Blach- $\varnothing$ rsten, M., Powers, M., Willig, I., \& Vera Zambrano, S. (2012). Media systems online and off: Comparing the form of news in the United States, Denmark, and France. Journal of Communication, 62(1), 21-38. https://doi.org/10.1111/j.1460-2466. 2011.01625.x

Berlo, D. K., Lemert, J. B., \& Mertz, R. J. (1969). Dimensions for evaluating the acceptability of message sources. Public Opinion Quarterly, 33(4), 563-576. https://doi.org/10.1086/267745

Bleyen, V.-A., \& van Hove, L. (2010). To bundle or not to bundle? How Western European newspapers package their online content. Journal of Media Economics, 23(3), 117-142. https://doi.org/10.1080/08997764. 2010.502511

Bruno, N., \& Nielsen, R. K. (2012). Survival is success: Journalistic online start-ups in Western Europe. Oxford: Reuters Institute for the Study of Journalism.

Chan-Olmsted, S. (2011). Media branding in a changing world: Challenges and opportunities 2.0. International Journal on Media Management, 13(1), 3-19. https://doi.org/10.1080/14241277.2011.568305

Chiou, L., \& Tucker, C. (2013). Paywalls and the demand for news. Information Economics and Policy, 25(2), 61-69. https://doi.org/10.1016/j.infoecopol. 2013.03.001

Chyi, H. I. (2005). Willingness to pay for online news: An empirical study on the viability of the subscription model. Journal of Media Economics, 18(2), 131-142. https://doi.org/10.1207/s15327736me1802_4

Chyi, H. I. (2012). Paying for what? How much? And why (not)?: Predictors of paying intent for multiplatform newspapers. International Journal on Media Management, 14(3), 227-250. https://doi.org/10.1080/ 14241277.2012.657284

Chyi, H. I., \& Chadha, M. (2011). News on new devices. Journalism Practice, 6(4), 431-449. https://doi.org/ 10.1080/17512786.2011.629125

Chyi, H. I., \& Lasorsa, D. L. (2002). An explorative study on the market relation between online and print newspapers. Journal of Media Economics, 15(2), 91-106. https://doi.org/10.1207/S15327736ME1502_2

Chyi, H. I., \& Lee, A. M. (2013). Online news consumption. 
Digital Journalism, 1(2), 194-211. https://doi.org/ 10.1080/21670811.2012.753299

Collins, R. (2011). Content online and the end of public media? The UK, a canary in the coal mine? Media, Culture \& Society, 33(8), 1202-1219. https://doi.org/ $10.1177 / 0163443711422459$

Cook, C., \& Sirkkunen, E. (2013). What's in a niche? Exploring the business model of online journalism. Journal of Media Business Studies, 10(4), 63-82. https:// doi.org/10.1080/16522354.2013.11073576

Cook, J. E., \& Attari, S. Z. (2012). Paying for what was free: Lessons from The New York Times paywall. Cyberpsychology, Behavior, and Social Networking, 15(12), 682-687. https://doi.org/10.1089/cyber.2012.0251

Curran, J., Fenton, N., \& Freedman, D. (2012). Misunderstanding the internet. London: Routledge.

Davison, W. P. (1983). The third-person effect in communication. Public Opinion Quarterly, 47(1), 1-15. https://doi.org/10.1086/268763

de Waal, E., Schönbach, K., \& Lauf, E. (2005). Online newspapers: A substitute or complement for print newspapers and other information channels? Communications, 30(1), 55-72. https://doi.org/10.1515/ comm.2005.30.1.55

Dimmick, J., Chen, Y., \& Li, Z. (2004). Competition between the internet and traditional news media: The gratification-opportunities niche dimension. The Journal of Media Economics, 17(1), 19-33. https:// doi.org/10.1207/s15327736me1701_2

Dutta-Bergman, M. (2004). Complementary in consumption of news types across traditional news media. Journal of Broadcasting and Electronic Media, 48(1), 41-61. https://doi.org/10.1207/ s15506878jobem4801_3

Filistrucchi, L. (2005). The impact of internet on the market for daily newspapers in Italy (EUI ECO Working Paper 12-2005). Fiesole: Department of Economics, European University Institute.

Flavian, C., \& Gurrea, R. (2009). Digital versus traditional newspapers: Influences on perceived substitutability. International Journal of Market Research, 51(5), 635-675. https://doi.org/10.1177/ 147078530905100503

Fletcher, R., \& Park, S. (2017). The impact of trust in the news media on online news consumption and participation. Digital Journalism, 5(10), 1281-1299. https:// doi.org/10.1080/21670811.2017.1279979

Fortunati, L., Deuze, M., \& de Luca, F. (2014). The new about news: How print, online, free and mobile coconstruct new audiences in Italy, France, Spain, the UK, and Germany. Journal of Computer-Mediated Communication, 19(2), 121-140. https://doi.org/ 10.1111/jcc4.12017

Gaziano, B. C., \& McGrath, K. (1986). Measuring the concept of credibility. Journalism and Mass Communication Quarterly, 63(3), 451-462. https://doi.org/ $10.1177 / 107769908606300301$

Goyanes, M. (2014). An empirical study of factors that influence the willingness to pay for online news. Journalism Practice, 8(6), 742-757. https://doi.org/ 10.1080/17512786.2014.882056

Goyanes, M., \& Vara-Miguel, A. (2017). Probabilidad de pagar por noticias digitales en España [Probability of paying for digital news in Spain]. El Profesional de la Información, 26(3), 488-496. https://doi.org/ 10.3145/epi.2017.may.15

Gundlach, H., \& Hofmann, J. (2017). Preferences and willingness to pay for tablet news apps. Journal of Media Business Studies, 14(4), 1-25. https://doi.org/ 10.1080/16522354.2017.1346948

Ha, L., \& Fang, L. (2012). Internet experience and time displacement of traditional news media use: An application of the theory of the niche. Telematics and Informatics, 29(2), 177-186. https://doi.org/10.1016/ j.tele.2011.06.001

Herbert, J., \& Thurman, N. (2007). Paid content strategies for news websites. Journalism Practice, 1(2), 208-226. https://doi.org/10.1080/1751278070127 5523

Himma-Kadakas, M., \& Kõuts, R. (2015). Who is willing to pay for online journalistic content? Media and Communication, 3(4), 106-115. http://dx.doi.org/ 10.17645/mac.v3i4.345

Holm, A. B. (2016). Could freemium models work for legacy newspapers? Nordicom Information, 38(1), 83-87. Retrieved from https://www.nordicom.gu. se/sites/default/files/kapitel-pdf/nordicominformation_38_2016_1_83-87.pdf

Hovland, C. I., \& Weiss, W. (1951). The influence of source credibility on communication effectiveness. The Public Opinion Quarterly, 15(4), 635-650. Retrieved from http://www.jstor.org/stable/2745952

Humprecht, E., \& Büchel, F. (2013). More of the same or marketplace of opinions? A crossnational comparison of diversity in online news reporting. The International Journal of Press/Politics, 18(4), 436-461. https://doi.org/10.1177/1940161213497595

Internet World Stats. (n.d.). Internet world stats. Internet World Stats. Retrieved from https://www. internetworldstats.com

Johnson, T. J., \& Kaye, B. K. (1998). Cruising is believing?: Comparing internet and traditional sources on media credibility measures. Journalism \& Mass Communication Quarterly, 75(2), 325-340. https://doi.org/ 10.1177/107769909807500208

Kammer, A., Boeck, M., Hansen, J. V., \& Hadberg, L. J. (2015). The free-to-fee transition: Audiences' attitudes toward paying for online news. Journal of Media Business Studies, 12(2), 107-120. https://doi.org/ 10.1080/16522354.2015.1053345

Kiousis, S. (2001). Public trust or mistrust? Perceptions of media credibility in the information age. Mass Communication \& Society, 4(4), 381-403. https://doi.org/ 10.1207/S15327825MCS0404_4

Kohring, M., \& Matthes, J. (2007). Trust in news media: Development and validation of a multidimensional 
scale. Communication Research, 34(2), 231-252. https://doi.org/10.1177/0093650206298071

Küng, L. (2008). Strategic management in the media: From theory to practice. Los Angeles, CA: Sage.

Küng, L., Picard, R. G., \& Towse, R. (2008). The internet and the mass media. London: Sage.

Lin, C., Salwen, M., \& Abdulla, R. (2005). Uses and gratifications of online and offline news: New wine in an old bottle. In M. B. Salwen, B. Garrison, \& P. D. Driscoll (Eds.), Online news and the public (pp. 221-236). Mahwah, NJ: Lawrence Erlbaum.

Lowe, G. F., \& Stavitsky, A. G. (2016). Ensuring public service news provision in the era of networked communications. International Communication Gazette, 78(4), 311-329. https://doi.org/10.1177/ 1748048516632163

McChesney, R. W. (2012). Farewell to journalism? Journalism Practice, 6(5/6), 614-626. https://doi.org/ 10.1080/17512786.2012.683273

McDowell, W. S. (2011). The brand management crisis facing the business of journalism. International Journal on Media Management, 13(1), 37-51. https:// doi.org/10.1080/14241277.2010.545364

Mensing, D. (2007). Online revenue business model has changed little since 1996. Newspaper Research Journal, 28(2), 22-37. https://doi.org/10.1177 $\% 2 F 073953290702800202$

Mitchelstein, E., \& Boczkowski, P. (2010). Online news consumption research: An assessment of past work and an agenda for the future. New Media \& Society, 12(7), 1085-1102. https://doi:10.1177/ 1461444809350193

Newell, J., Pilotta, J. J., \& Thomas, J. C. (2008). Mass media displacing and saturation. International Journal on Media Management, 10(4), 131-138. https:// doi.org/10.1080/14241270802426600

Newman, N., Fletcher, R., Kalogeropoulos, A., \& Nielsen, R. (2019). Reuters Institute digital news report 2019. Oxford: Reuters Institute for the Study of Journalism.

Newman, N., Levy, D. A., \& Nielsen, R. K. (2015). Reuters Institute digital news report 2015: Tracking the future of news. Oxford: Reuters Institute for the Study of Journalism.

Nicholls, T., Shabbir, N., \& Nielsen, R. K. (2016). Digitalborn news media in Europe. Oxford: Reuters Institute for the Study of Journalism.

Oh, H., Animesh, A., \& Pinsonneault, A. (2016). Free versus for-a-fee: The impact of a paywall. MIS Quarterly, 40(1), 31-56.

Organization for Economic Co-operation and Development. (2010). The evolution of news and the internet (DSTI/ICCP/IE [2009] 14/FINAL). Paris: Organization for Economic Co-operation and Development. Retrieved from http://www.oecd.org/internet/ ieconomy/45559596.pdf

Ots, M. (2010). Understanding value formation (Unpublish Doctoral dissertation). Jönköping International Business School, Jönköping, Sweden.
Perloff, R. M. (2009). Mass media, social perception, and the third-person effect. In J. Bryant \& M. B. Oliver (Eds.), Media effects (pp. 268-284). New York, NY: Routledge.

Pickard, V., \& Williams, A. T. (2014). Salvation or folly? The promises and perils of digital paywalls. Digital Journalism, 2(2), 195-213. https://doi.org/10.1080/ 21670811.2013.865967

Siegert, G., Förster, K., Chan-Olmsted, S. M., \& Ots, M. (2015). Handbook of media branding. Cham: Springer.

Siegert, G., Gerth, M. A., \& Rademacher, P. (2011). Brand identity-driven decision making by journalists and media managers: The MBAC model as a theoretical framework. International Journal on Media Management, 13(1), 53-70. https://doi.org/ $10.1080 / 14241277.2010 .545363$

Sjøvaag, H. (2016). Introducing the paywall. Journalism Practice, 10(3), 304-322. https://doi.org/10.1080/ 17512786.2015.1017595

Stetka, V., \& Örnebring, H. (2013). Investigative journalism in Central and Eastern Europe: Autonomy, business models, and democratic roles. The International Journal of Press/Politics, 18(4), 413-435. https://doi. org/10.1177/1940161213495921

Tsfati, Y. (2010). Online news exposure and trust in the mainstream media: Exploring possible associations. American Behavioral Scientist, 54(1), 22-42. https:// doi.org/10.1177/0002764210376309

Tsfati, Y., \& Cappella, J. N. (2003). Do people watch what they do not trust?: Exploring the association between news media skepticism and exposure. Communication Research, 30(5), 504-529. https://doi.org/ 10.1177/0093650203253371

Tsfati, Y., \& Cappella, J. N. (2005). Why do people watch news they do not trust? The need for cognition as a moderator in the association between news media skepticism and exposure. Media Psychology, 7(3), 251-271. https://doi.org/10.1207/ S1532785XMEP0703_2

Tungate, M. (2005). Media monoliths: How great media brands thrive and survive. London: Kogan Page.

Vara-Miguel, A., Sanjurjo-San Martín, S. S., \& DíazEspina, C. (2014). Paid news vs free news: Evolution of the WSJ.com business model from a content perspective (2010-2012). Communication \& Society, 27(2), 147-167. https://doi.org/10.15581/003.27.2. 147-167

Wang, Y. (2011). Making online pay: The prospect of the paywall in a digital and networked economy. Journal of Digital Research and Publishing, 1, 14-21.

Webster, J. G., \& Ksiazek, T. B. (2012). The dynamics of audience fragmentation: Public attention in an age of digital media. Journal of Communication, 62(1), 39-56. https://doi.org/10.1111/j.1460-2466. 2011.01616.x

Westley, B. H., \& Severin, W. J. (1964). Some correlates of media credibility. Journalism Quarterly, 41(1), 
325-335. https://doi.org/10.1177/1077699064041 00301

Westlund, O., \& Färdigh, M. A. (2011). Displacing and complementing effects of news sites on newspapers 1998-2009. International Journal of Media Management, 13(3), 177-194. https://doi.org/10.1080/ 14241277.2011.595020

Westlund, O., \& Färdigh, M. A. (2012). Conceptualizing media generations: The print, online and individualized generations. Observatorio (OBS*), 6(4), 181-213. https://doi.org/10.15847/obsOBS 642012616

Westlund, O., \& Färdigh, M. A. (2015). Accessing the news in an age of mobile media: Tracing displacing and complementary effects of mobile news on newspapers and online news. Mobile Media \& Communication, 3(1), 53-74. https://doi.org/10.1177/ 2050157914549039

\section{About the Author}

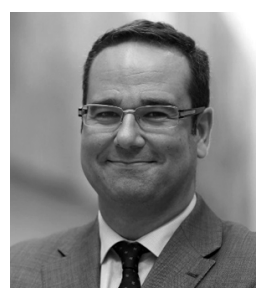

Alfonso Vara-Miguel is Associate Professor at the School of Communication of the University of Navarra (Spain), where he teaches Economics, Financial Journalism, Media Management, and Pricing. Since 2014, he is a research member of the Digital unav-Center for Internet Studies and Digital Life at the University of Navarra and co-author of the design and analysis of the annual Spain Digital News Report, in cooperation with the Reuters Institute for the Study of Journalism (Oxford University). 